\title{
Evaluasi Program Sekolah Dasar Bersih dan Sehat: Studi Pada Madrasah Ibtidaiyah di Kota Bandar Lampung
}

\section{Evaluation of a Clean and Healthy Primary School program: A Study of Islamic Education in Bandar Lampung City}

\author{
Samino', Dwi Astuti Widia Ningrum ${ }^{1}$, Silvia Dewi Ratna Sari ${ }^{1}$ \\ ${ }^{1}$ Fakultas Kesehatan Masyarakat Universitas Malahayati, Bandar Lampung, \\ Indonesia \\ *korespondensi Penulis: saminomartono13@gmail.com
}

Penyerahan: 29-08-2020, Perbaikan: 13-09-2020, Diterima: 25-09-2020

\begin{abstract}
Primary school-age children are a critical age group because a child is vulnerable to health problems. Health issues that are more prominent in elementary school-age children are clean and healthy behaviors. To support the quality of clean and healthy life for all school residents, a Clean and Healthy Elementary School (SDBS) Development program is needed. Nowadays, implementing a clean and healthy elementary school program needs continuously evaluated to measure program implementation success. This research is descriptive qualitative, with the Head of Madrasah Ibtidaiyah in Bandar Lampung City as the sample. Data collected by document review, observation, and interview. Data were analyzed by data reduction, data presentation, and conclusion (data verification). Based on the research, the success of clean and healthy elementary school programs has only reached $C$. The results show that the leading cause of unsuccess of a clean and healthy school program is internal and external factors, such as the lack of facilities and collaboration, which is not going well.
\end{abstract}

Keywords: Clean and Healthy Elementary School, Madrasah Ibtidaiyah.

\section{ABSTRAK}

Anak usia sekolah dasar merupakan kelompok usia yang kritis karena seorang anak rentan terhadap masalah kesehatan. Isu kesehatan yang lebih menonjol pada anak usia sekolah dasar adalah perilaku hidup bersih dan sehat. Untuk mendukung peningkatan kualitas hidup bersih dan sehat kepada seluruh warga sekolah tersebut maka diperlukan program Pembinaan Sekolah Dasar Bersih dan Sehat (SDBS). Namun saat ini pelaksanaan program sekolah dasar bersih dan sehat perlu dievalusi secara berkesinambungan untuk mengukur keberhasilan pelaksanaan program. Jenis penelitian ini adalah deskriptif kualitatif, dengan sampel Kepala Madrasah Ibtidaiyah di Kota Bandar Lampung. Teknik pengumpulan data yaitu kajian dokumen, observasi dan wawancara mendalam. Teknik analisis data menggunakan reduksi data, penyajian data, dan pengambilan kesimpulan (verifikasi data). Berdasarkan penelitian yang telah dilakukan keberhasilan program sekolah dasar bersih dan sehat baru mencapai peringkat C (Cukup). Dari hasil penelitian faktor internal dan eksernal seperti kurangnya dukungan sarana dan prasarana yang ada serta kerjasama antar warga sekolah yang belum terjalin dengan baik menjadi penyebab belum berhasilnya program sekolah dasar bersih dan sehat.

Kata kunci: SDBS, madrasah ibtidaiyah.

Jurnal Dunia Kesmas, Vol. 9 No. 3, Juli 2020, hal. 423-433

ISSN 2301-6604 (Print), ISSN 2549-3485 (Online)

http://ejurnalmalahayati.ac.id/index.php/duniakesmas/index 


\section{PENDAHULUAN}

Sekolah sehat adalah lingkungan hidup sekolah yang sehat, mencakup keseluruhan kondisi fisik, mental dan sosial dari suatu sekolah. Pendidikan kesehatan di sekolah, khususnya SD/MI dirancang untuk membekali siswa agar memiliki pengetahuan yang cukup mengenai kesehatan, khususnya perilaku sehat yang harus diimplementasikan setiap hari atau biasa disebut perilaku hidup bersih dan sehat (PHBS) (Kementrian Kesehatan RI,2013).

Sekolah Dasar dan Sehat (SD Bersih Sehat) adalah sekolah yang warganya secara terus-menerus membudayakan perilaku hidup bersih dan sehat, memiliki lingkungan sekolah yang bersih, indah sejuk, segar, rapih, tertib dan aman. Upaya mewujudkan sekolah dasar bersih dan sehat dapat dicapai melalui strategi penyediaan sarana dan prasarana, manajemen yang baik, penyebarluasan pengetahuan, penciptaan kondisi ideal dengan melibatkan partisipasi semua pihak seperti warga sekolah, komite sekolah, puskesmas dan masyarakat (Kementerian Pendidikan dan kebudayaan, 2013). Ada 2 (tiga) indikator/variabel utama dalam penilaian keberhasilan program SDBS yaitu sarana dan prasarana, dan budaya bersih dan sehat.

Provinsi Lampung data SD yang tidak memiliki air layak atau tidak ada sumber air mencapai 23,62\%. Untuk akses jamban tidak layak atau tidak ada jamban $8,25 \%$, sementara untuk jamban layak namun tidak terpisah mencapai $63,18 \%$ dan untuk SD yang memiliki akses tempat cuci tangan baru mencapai 39,5\% (Kementerian Pendidikan dan
Kebudayaan, 2017). Sedangkan data Cakupan PHBS di Provinsi Lampung 2015 sebesar 60\% (target: 62\%) Cakupan penjaringan dan pelayanan kesehatan siswa SD/MI dan sederajat 2014 sebesar 89,96\%, angka ini belum mencapai target yang diharapkan (95\%) (Dinas Kesehatan Kota Bandar Lampung, 2014).

Hasil observasi di dua Madrasah Ibtidaiyah yang berada di Kota Bandar Lampung diketahui bahwa dari kedua madrasah ibtidaiyah tersebut belum memenuhi syarat sekolah sehat dan bersih dikarenakan lantai yang masih kotor, dinding mengelupas, jumlah kotak sampah sedikit, belum tersedia (jamban, tempat cuci tangan dan UKS). Donald P.Warwick mengatakan bahwa dalam tahap implementasi program terdapat dua faktor yang mempengaruhi keberhasilan yaitu faktor pendorong (Facilitating conditions), dan faktor penghambat (Impending conditions). Melakukan evaluasi program adalah kegiatan yang dimaksudkan untuk mengetahui seberapa tinggi tingkat keberhasilan dari kegiatan yang direncanakan (Arikunto, 2018). Tujuan diketahui keberhasilan pelaksanaan program Sekolah Dasar Bersih dan Sehat di Madrasah Ibtidaiyah Kota Bandar Lampung. Indikator Budaya Hidup Bersih dan Sehat yang terdiri dari sosialisasi SDBS, kegiatan kepala sekolah, tenaga pendidik, tenaga kependidikan, siswa, dan komite sekolah. Keberhasilan program SDBS, tersebut jika dilaksanakan dengan penuh, maka akan memperoleh skor 100. Diskripsi hasil akhir penilaian dikategorikan sebagai berikut:Skor: 90.50-100 : Peringkat

Jurnal Dunia Kesmas, Vol. 9 No. 3, Juli 2020, hal. 423-433 
A, dengan kategori Sangat Baik; Skor: 70.50-90.00: Peringkat B, dengan kategori Baik; Skor: 50.5070 : Peringkat $D$, dengan kategori Kurang.

\section{METODE}

Penelitian ini adalah penelitian deskriptif kualitatif dengan desain penelitian menggunakan pendekatan studi kasus (Sugiyono, 2017). Sampel yang digunakan adalah lima madrasah ibtidaiyah yaitu MIN 3, MIN 6, MIN 9 MI Hidayatul Islamiyah, MI Ismaria Al-
Qur'anniyah. Pemilihan lokasi penelitian (informan) untuk penelitian ini menggunakan teknik Snowball. Teknik pengumpulan data pada penelitian ini menggunakan kajian dokumen, observasi, dan wawancara mendalam. Alat pengumpul data yang digunakan adalah Lembar Observasi, metode wawancara, buku catatan dan kamera. Prosedur pengumpulan data dilakukan dengan orientasi lapangan, tahap discovery, Tahapan Explanation.

HASIL

Tabel 1. Distribusi Sarana dan Prasarana di Madrasah Ibtidaiyah Kota Bandar Lampung 2019

\begin{tabular}{|c|c|c|c|c|c|c|c|c|}
\hline \multirow[b]{2}{*}{ No } & \multirow[b]{2}{*}{ Indikator } & \multicolumn{5}{|c|}{ Nilai Akhir Mi } & \multirow{2}{*}{$\begin{array}{c}\text { Nilai } \\
\text { Standar } \\
\text { Maksimu } \\
\text { m } \\
\end{array}$} & \multirow[b]{2}{*}{$\%$} \\
\hline & & $\begin{array}{l}\text { M- } \\
\text { III }\end{array}$ & M-VI & M-IX & M-HI & M-IA & & \\
\hline 1 & $\begin{array}{l}\text { Visi, Misi, } \\
\text { Tujuan dan } \\
\text { Sasaran }\end{array}$ & 2,40 & 1,80 & 1,80 & 1,80 & 1,80 & 3,00 & 64 \\
\hline 2 & RKS/RKAS & 2,00 & 0,67 & 2,00 & 2,00 & 0,67 & 2,00 & 73 \\
\hline 3 & $\begin{array}{l}\text { Bangunan } \\
\text { sekolah }\end{array}$ & 7,20 & 8,32 & 5,92 & 6,24 & 6,40 & 10.00 & 68 \\
\hline 4 & $\begin{array}{l}\text { Sarana } \\
\text { Kebersihan }\end{array}$ & 0,51 & 0,68 & 0,51 & 0,43 & 0,51 & 1,00 & 53 \\
\hline 5 & KM/WC/Urinoir & 2,42 & 1,98 & 1,76 & 1,32 & 1,32 & 4,00 & 51 \\
\hline 6 & UKS & 1,43 & 3,99 & 0,57 & 2,28 & 2,00 & 4,00 & 44 \\
\hline 7 & Kantin & 0 & 1,32 & 0 & 0 & 0 & 4,00 & 7 \\
\hline 8 & $\begin{array}{l}\text { Halaman dan } \\
\text { Lingkungan } \\
\text { Sekolah }\end{array}$ & 3,99 & 3,71 & 3,42 & 3,42 & 3,42 & 4,00 & 89 \\
\hline 9 & $\begin{array}{l}\text { Sumber Air dan } \\
\text { Sanitasi }\end{array}$ & 4,00 & 3,20 & 4,00 & 3,60 & 3,60 & 4,00 & 92 \\
\hline 10 & $\begin{array}{l}\text { Tempat } \\
\text { Sampah }\end{array}$ & 0,67 & 2,00 & 2,00 & 2,00 & 2,00 & 4,00 & 43 \\
\hline \multirow{2}{*}{\multicolumn{2}{|c|}{ Jumlah }} & 24,62 & 27,66 & 21,99 & 23,09 & 21,71 & 40,00 & \multirow{2}{*}{$\begin{array}{l}59,5 \\
2\end{array}$} \\
\hline & & \multicolumn{6}{|c|}{23,81} & \\
\hline
\end{tabular}

Hasil penelitian menunjukan tingkat pencapaian indikator sarana dan prasarana rata-ratanya baru mencapai 23,81 (59,52\%), artinya tingkat keterpenuhannya baru mencapai 59,52\%, masih

Jurnal Dunia Kesmas, Vol. 9 No. 3, Juli 2020, hal. 423-433

ISSN 2301-6604 (Print), ISSN 2549-3485 (Online)

http://ejurnalmalahayati.ac.id/index.php/duniakesmas/index 
membutuhkan 39,48\% untuk indikator keterpenuhan sarana dan mencapai kelangkapan dan prasarana madrasah sehat adalah kualitasnya. Pencapaian sarana dan sumber air bersih dan sanitasi prasarana madrasah paling rendah lingkungan (92\%) sedangkan yang $(21,71)$ adalah $\mathrm{M}-\mathrm{HI}$, dan paling paling rendah pencapaiannya tinggi $(27,66)$ M-VI. Sementara keberadaan kantin sehat $(7 \%)$. 1. Budaya Bersih dan Sehat di Madrasah Ibtidaiyah Kota Bandar Lampung tahun 2019.

Tabel 2. Distribusi Budaya Bersih dan Sehat dalam Program SDBS di Madrasah Ibtidaiyah Kota Bandar Lampung

\begin{tabular}{|c|c|c|c|c|c|c|c|c|}
\hline \multirow[b]{2}{*}{ No } & \multirow[b]{2}{*}{ Indikator } & \multicolumn{5}{|c|}{ Nilai Akhir } & \multirow{2}{*}{$\begin{array}{c}\text { Nilai } \\
\text { Standar } \\
\text { Maksimu } \\
\text { m }\end{array}$} & \multirow[b]{2}{*}{$\%$} \\
\hline & & M-III & M-VI & M-IX & $\mathrm{M}-\mathrm{HI}$ & M-IA & & \\
\hline 1 & $\begin{array}{l}\text { Sosialisasi Sekolah } \\
\text { Bersih dan Sehat }\end{array}$ & 5,00 & 7,50 & 7,50 & 5,00 & 7,50 & 10,00 & 65 \\
\hline 2 & \multicolumn{8}{|c|}{ Kegiatan Warga Sekolah } \\
\hline & $\begin{array}{l}\text { a. Kepala } \\
\text { sekolah }\end{array}$ & 6,25 & 8,75 & 6,25 & 6,25 & 6,25 & 10,00 & 68 \\
\hline & $\begin{array}{l}\text { b. Tenaga } \\
\text { pendidik }\end{array}$ & 8,75 & 10,00 & 10,00 & 10,00 & 10,00 & 10,00 & 98 \\
\hline & $\begin{array}{lc}\text { c. } & \text { Tenaga } \\
\text { Kependidikan }\end{array}$ & 2,50 & 1,25 & 2,50 & 2,50 & 2,50 & 5,00 & 45 \\
\hline & d. $\quad$ Siswa & 12,87 & 15,73 & 15,73 & 12,87 & 10,00 & 20,00 & 67 \\
\hline & e. Komite & 0 & 2,50 & 0 & 0 & 0 & 5,00 & 10 \\
\hline \multicolumn{2}{|c|}{ Jumlah } & 35,37 & 45,73 & 41,95 & 36,62 & 36,26 & 60,00 & \multirow{2}{*}{63,3} \\
\hline \multicolumn{2}{|c|}{ Nilai Rata-Rata } & \multicolumn{6}{|c|}{39,18} & \\
\hline
\end{tabular}

Berdasarkan tabel 2 dapat dijelaskan bahwa tingkat pencapaian pembudayaan madrasah bersih dan sehat nilai paling tinggi diperoleh MIN-06 (45.73) dan terendah pada M-III $(35,37)$. Nilai rata-rata MI di Kota Bandar Lampung baru mencapai $39,18 \quad(63,30 \%)$ artinya baru mencapai kategori cukup. Sementara itu pembudayaan yang dilakukan oleh tenaga pendidik merupakan indikator ketercapaiannya paling tinggi (98\%) dan paling rendah keterlibatan komite $(10 \%)$.

Tabel 3. Evaluasi Keberhasilan Program SDBS di beberapa MI Kota Bandar Lampung

\begin{tabular}{|l|l|c|c|}
\hline No & Kode Madrasah & Skor & Kategori \\
\hline 1 & M-III & 59,99 & C \\
\hline 2 & M-VI & $\mathbf{7 3 , 3 9}$ & B \\
\hline 3 & M-IX & 63,96 & C \\
\hline 4 & M-HI & 59,71 & C \\
\hline 5 & M-IA & $\mathbf{5 7 , 9 7}$ & C \\
\hline \multicolumn{2}{|c|}{ Nilai rata-rata } & $\mathbf{6 2 , 9 7}$ & C \\
\hline
\end{tabular}

Jurnal Dunia Kesmas, Vol. 9 No. 3, Juli 2020, hal. 423-433 
Hasil penelitian menunjukkan keberhasilan program SDBS di lokasi penelitian memperoleh nilai rata-rata program SDBS tersebut masih rendah. Hanya satu madrasah ibtidaiyah yang memperoleh nilai

\section{PEMBAHASAN}

Hasil penelitian menunjukan tingkat pencapaian indikator sarana dan prasarana baru mencapai 23,81 $(59,52 \%)$, artinya tingkat keterpenuhannya baru mencapai hampir 60\%, masih membutuhkan $40 \%$ lebih untuk mencapai kelengkapan dan kualitasnya. Dengan kata lain tingkat keterpenuhan dan kualitas sarana dan prasananya dalam kategori cukup. Sarana dan prasarana yang dibutuhkan untuk memenuhi madrasah sehat adalah visi, misi, sasaran, RKS/RKAS, bangunan sekolah, sarana kebersihan, kamar mandi/WC/urinoir, UKS, kantin, halaman dan lingkungan sekolah, sumber air dan sanitasi, dan tempat sampah. Sarana dan prasarana memenuhi standar madrasah sehat baik jika kesepuluh indikator tersebut dapat dipenuhi secara fisik serta kualitasnya (Kementerian Pendidikan dan kebudayaan, 2013). Penelitian Devi (2018), menyatakan bahwa keberadaan sarana dan prasarana merupakan komponen penting dalam lembaga pendidikan karena dapat menunjang keberhasilan proses belajar mengajar. Tanpa sarana dan prasarana maka proses pembelajaran pendidikan kesehatan berjalan kurang baik. Sejalan dengan hal tersebut penelitian Handayani
62.97 dengan peringkat C (cukup), dengan demikian dapat disimpulkan bahwa pelaksanaan baik $(73,39)$ dengan kategori baik, selebihnya cukup.

(2008), menyatakan bahwa fasilitas/sarana di posisikan sebagai faktor pendukung keberhasilan suatu program.

Berdasarkan hasil penelitian diketahui komponen sarana dan prasarana rata-rata dilima madrasah yang pencapaiannya belum memenuhi standar adalah keberadaan dan kualitas UKS memiliki nilai rendah. Secara umum dapat dikatakan bahwa kualitas dan keberasaan UKS dilima madrasah belum memenuhi standar yang ditentukan, seperti M-IX tidak memiliki ruang khusus UKS. Kondisi ini disebabkan tidak ada ruangan yang bisa dimanfaatkan UKS. Lahan madrasah sangat sempit dan sudah penuh dengan bangunan ruang kelas. Selain MIN-09, kondisi juga terjadi pada M-III, madrasah tersebut memiliki ruang UKS, namun ruangan tersebut juga digunakan sebagai gudang (penyimpanan alat pramuka) serta ruang keamanan. Rendahnya kualitas UKS juga dialami $\mathrm{M}-\mathrm{HI}$, benar memiliki ruangan, namun kualitas kelengkapannya belum memadai, hanya memiliki tempat tidur periksa dan kotak P3K. M-IA memiliki ruang UKS memadai namun kelengkapanya belum memenuhi standard, seperti tempat tidur periksa yang sudah rusak (patah), kelengkapan sarana pengobatan dasar tidak ada, kotor, diperkirakan tidak dimanfaatkan dengan baik. Hanya M-VI yang

Jurnal Dunia Kesmas, Vol. 9 No. 3, Juli 2020, hal. 423-433

ISSN 2301-6604 (Print), ISSN 2549-3485 (Online)

http://ejurnalmalahayati.ac.id/index.php/duniakesmas/index 
memiliki UKS hampir memenuhi standar (sudah baik), ruangan memadahi, terdapat KM/WC, kelangkapan didalamnya hampir terpenuhi, serta terdapat pengelola yang jelas. Hasil penelitian menemukan bahwa rata-rata petugas UKS yang ditugaskan belum kompeten dalam bidangnya.

Sarana lain adalah keberadaan dan kualitas kantin tingkat pencapaiannya masih rendah. Fasilitas tempat sampah juga tingkat pencapaiannya rendah, karena ketersediaan tempat sampah di lima madrasah rata-rata belum terpenuhi. Hanya tersedia tempat sampah terbuka disetiap depan ruang kelas dan tidak terpilah, bahkan sebagian menggunakan bak dari papan sehingga jika ada anak yang membuang bekas minuman, airnya berceceran, sebagian lain menggunakan ember plastik bekas cat $20 \mathrm{~kg}$.

Peneliti berpendapat bahwa belum tercapainya nilai indikator sarana dan prasarana kelima madrasah tersebut disebabkan belum adanya kemauan yang kuat dari internal madrasah maupun dari pengambil kebijakan baik ditingkat madrasah, Kemenag Kota Bandar Lampung maupun Dinas pendidikan Kota Bandar Lampung. Madrasah belum mampu mengambil langkah strategis dalam menyelesaikan persoalan tersebut. Persoalan klasik adalah kekurangan dana, namun sesungguhnya tidak semuanya harus diselesaikan dengan dana, bisa diselesaikan dengan cara lain. Ada madrasah yang sesungguhnya secara finansial mampu untuk memenuhi kebutuhan namun ternyata tidak mampu memenuhi kebutuhan sarana dan prasarana tersebut. Madrasah dengan siswa sedikit,maka dana BOS yang diterima juga sedikit, maka tidak mampu untuk memenuhi kebutuhan yang prinsip seperti memenuhi honorarium guru honorer, kebutuhan yang lain bisa ditunda.

Berdasarkan hal tersebut peneliti berasumsi bahwa tiap madrasah belum mampu memenuhi kebutuhan sarana dan prasarana disebabkan masih mengandalkan dana dari Kementerian Agama, seharusnya bisa memberdayakan warga sekolah untuk menciptakan hal baru guna memenuhi kebutuhan sarana dan prasarana yang belum terpenuhi. Sebagai contoh melaksanakan kerja sama dengan warga sekolah untuk melakukan kegiatan 3R (Recycle, reduce, reuse) dimana kegiatan tersebut mampu menghasilkan uang sehingga diharapkan mampu memenuhi sarana dan prasarana yang dibutuhkan.

Hasil penelitian menunjukan tingkat pencapaian indikator budaya bersih dan sehat pada madrasah ibtidaiyah Kota Bandar Lampung baru mencapai 39,18 (63,30\%) artinya baru mencapai kategori cukup. Hasil penelitian ini senada dengan hasil penelitian (Diana, 2014) menunjukan bahwa lebih dari separoh siswa belum melaksanakan Program Perilaku Hidup Bersih dan Sehat (PHBS) yaitu 54,7\% seperti pada SD Negeri 001 Tanjung Balai Karimun Kabupaten Karimun Tahun 2013 Hal ini sama dengan penelitian yang dilakukan oleh Anshori di SMPN 258 Kel.Cibubur Tahun 2011 bahwa siswa yang belum melaksanakan Program Perilaku Hidup Sehat dan Bersih (PHBS) yaitu sebesar 56\% (Anshori,2011). Dengan kata lain masih ada $36.7 \%$ yang harus

Jurnal Dunia Kesmas, Vol. 9 No. 3, Juli 2020, hal. 423-433

428

ISSN 2301-6604 (Print), ISSN 2549-3485 (Online)

http://ejurnalmalahayati.ac.id/index.php/duniakesmas/index 
dipenuhi agar mencapai pembudayaan bersih dan sehat benar-benar terlaksana 100\%, sehingga madrasah bersih dan sehat termasuk semua warganya.

Berdasarkan hasil penelitian diketahui adanya sosialisasi internal yang dilakukan oleh kepala madrasah sudah baik, seperti mensosialisasikan pentingnya menjaga kebersihan halaman, kelas, kamar mandi, maupun kebersihan diri seperti memotong kuku seminggu sekali, makan makanan sehat seperti minum susu, makan buah dan sayur. Hal itu disampaikan saat upacara rutin hari senin, serta pada saat rapat dengan guru dan staf. Selain itu sebagian madrasah telah memasang selogan-selogan berisi ajakan hidup bersih dan sehat. Ketut sulastri (2014) dalam penelitiannya menyebutkan bahwa cara membentuk perilaku siswa adalah dengan condisioning atau kebiasaan. Dengan cara membiasakan diri untuk beperilaku seperti yang diharapkan, akhirnya akan terbentuklah perilaku tersebut. Kepala madrasah selalu mengajak warganya untuk bersama-sama menciptakan madrasah bersih dan sehat dengan melaksanakan kerja bakti (Jum'at bersih) seperti mengadakan kegiatan membersihkan lingkungan internal dan eksternal madrasah. Kegiatan eksternal madrasah hanya dilakukan beberapa madrasah. Jangkauannya ada yang beberapa rumah namun ada yang sampai puluhan rumah. Hermiyanti (2016), mengatakan salah satu kegiatan yang dilakukan untuk menunjang program sekolah dasar bersih dan sehat adalah dengan melakukan kegiatan sabtu bersih, merupakan kerja bakti yang dilakukan oleh semua warga sekolah untuk menjaga lingkungan agar tetap bersih dan sehat serta menjaga fasilitas/sarana program madrasah bersih dan sehat.

Hal-hal tidak mendukung budaya bersih dan sehat adalah masih ada beberapa anggota warga madrasah perilakunya belum mencerminkan budaya hidup bersih dan sehat, seperti ada yang membuang sampah sembarangan, tenaga kependidikan serta penunjang merokok dilingkungan madrasah. Perilaku buruk tersebut disebabkan belum adanya kesadaran dari pribadi masing-masing untuk menjadi model berperilaku hidup bersih dan sehat dimanapun dia berada khususnya di madrasah. Berdasarkan hal tersebut peneliti berasumsi bahwa budaya bersih dan sehat di madrasah belum sepenuhnya diterima oleh semua warga madrasah, oleh sebab itu disarankan kepada kepala sekolah untuk melakukan kegiatan secara continue dimana kegiatan tersebut secara tidak sengaja akan melatih warga sekolah untuk berperilaku hidup bersih dan sehat seperti kegiatan sabtu bersih atau Jum'at Bersih yang dilaksanakan setiap minggunya sehingga diharapkan menciptakan budaya baru di madrasah.

\section{Evaluasi Keberhasilan Program SDBS MI Kota Bandar Lampung}

Hasil penelitian menunjukkan keberhasilan program SDBS di beberapa madrasah, nilai rata-rata 62,97 dengan peringkat $C$ (cukup), dengan demikian dapat disimpulkan bahwa pelaksanaan program SDBS di MI Kota Bandar Lampung masih rendah. Hasil ini menunjukkan bahwa cita-cita untuk menjadikan

Jurnal Dunia Kesmas, Vol. 9 No. 3, Juli 2020, hal. 423-433 
madrasah bersih dan sehat masih memerlukan strategi-strategi yang efektif dan efisien. Penelitian Zubaidah dkk (2016), mengatakan upaya mewujudkan sekolah dasar bersih dan sehat dapat dicapai melalui strategi penyediaan sarana dan prasarana, manajemen yang baik, penyebarluasan pengetahuan, penciptaan kondisi ideal dengan melibatkan partisipasi semua pihak seperti warga sekolah, komite sekolah, puskesmas, dan masyarakat.

Masih rendahnya pembudayaan perilaku hidup bersih dan sehat, salah satu informan (M-III) menyatalan hal ini disebabkan kurangnya kepedulian warga sekolah terhadap budaya hidup bersih dan sehat. Termasuk UKS, fisik dan kelengkapannya sangat terbatas, masih jauh dari kesempurnaan UKS yang sesungguhnya, termasuk kepemilikan kantin sehat. Permasalahan yang ada di M-VI adalah kantin sehat yang belum memadai, halaman sekolah yang tergenang air saat hujan, kamar mandi siswa yang perlu diperbaiki dalam segi kebersihannya serta kurangnya kerjasama antar warga sekolah dalam menciptakan budaya hidup bersih dan sehat dilingkungan madrasah, adanya siswa yang membuang sampah sembarangan, serta ada tenaga kependidikan madrasah yang merokok dilingkungan sekolah. Kepala sekolah telah melakukan sosialisasi dengan baik seperti menghimbau kepada warga sekolah untuk menjaga kebersihan dan mengingatkan untuk tidak merokok dilingkungan sekolah, adapun strategi perbaikan kantin yang dilakukan oleh kepala sekolah yaitu melakukan kerja sama dengan komite sekolah, namun belum terealisasi karena ada himbauan dari Kementerian Agama Kota Bandar Lampung untuk tidak menarik dana apapun dari komite.

M-IX yang menjadi permasalahan yaitu tidak tersedianya lahan disekolah untuk digunakan dalam penambahan ruangan terutama untuk pembangunan ruang khusus untuk UKS, dana yang tersedia juga belum tersedia untuk memenuhi kebutuhan tersebut. Permasalahan yang ada di $\mathrm{M}-\mathrm{HI}$ yaitu keadaan kamar mandi siswa, kamar mandi yang ada digunakan oleh semua tingkatan sekolah (MI, MTS, dan $M A)$, kondisinya buruk, kotor dan berbau, tidak memiliki pintu dan tidak terpisah antara laki-laki dan perempuan, serta dana yang ada kurang karena hanya mengandalkan dari dana BOS, tidak melibatkan orang tua siswa dengan pertimbangan jika memungut biaya apapun dari orang tua siswa maka dikhawatirkan tidak ada lagi yang bersekolah di madrasah tersebut dan memilih bersekolah ke Sekolah Dasar lainnya karena gratis biaya sekolah.

Penelitian sebelumnya yang menemukan faktor penghambat dari pelaksanaan sekolah dasar sehat dan bersih yaitu Kesadaran orangtua/masyarakat tentang peraturan tata tertib di sekolah masih kurang, kesadaran siswa tentang makanan sehat masih kurang dan adanya keterbatasan waktu dari petugas Puskesmas untuk membimbing siswa (Herdita Nurha, 2017) berkaitan dengan hal tersebut penelitian Diana menunjukkan bahwa pelaksanaan program perilaku hidup bersih dan sehat masih rendah dapat

Jurnal Dunia Kesmas, Vol. 9 No. 3, Juli 2020, hal. 423-433

430

ISSN 2301-6604 (Print), ISSN 2549-3485 (Online)

http://ejurnalmalahayati.ac.id/index.php/duniakesmas/index 
mengakibatkan kualitas lingkungan sekolah yang rendah dan bermuara pada tingginya angka penyakit yang menyerang anak usia sekolah. Upaya kepala madrasah untuk memenuhi berbagai kekurangan tersebut sudah melakukan sosialisasi pada warganya untuk selalu membudayakan hidup bersih dan sehat. Melakukan kerja bakti dengan program Jum'at bersih, didalam maupun luar madrasah. Kegiatan ini diharapkan dapat memicu warganya untuk membudayakan hidup bersih dan sehat. Keberhasilan program SDBS di Madrasah Ibtidaiyah masih jauh dari harapan, hal tersebut disebabkan oleh berbagai kendala yang dialami madrasah dalam penciptaan sekolah dasar bersih dan sehat. Namun sesungguhnya semua kegiatan yang dilakukan berkaitan dengan program SDBS hampir sepenuhnya terlaksana namun kendala utama dalam menjalankan program dengan maksimal yaitu persoalan dana.

\section{Strategi Penciptaan SDBS di beberapa Madrasah Ibtidaiyah Kota Bandar Lampung.}

Kepala madrasah, dalam menangani permasalahan tersebut dimasingmasing madrasah akan melakukan berbagai strategi untuk menciptakan sekolah bersih dan sehat, dalam hal itu ada 2 strategi yang akan dilakukan yang pertama yaitu bersama sama warga sekolah bekerjasama untuk menciptakan sekolah bersih dan sehat di madrasah, dan yang kedua dengan melakukan kerjasama dengan pihak ketiga. Hal tersebut sejalan dengan penelitian Maghfiroh, dkk (2016) yang mengatakan Strategi yang dilakukan oleh kepala sekolah dalam meningkatkan sarana antara lain dengan mengelola dana yang didapat dari pemerintah se-efisien mungkin, agar bisa digunakan untuk keperluan lain yang menyangkut pemenuhan kebutuhan pembelajaran di sekolah tersebut. Kepala sekolah pun juga harus mempunyai tim yang mendukung dan membantu dalam proses meningkatkan kualitas sekolah yang dipimpinnya. Perubahan yang dilakukan oleh kepala sekolah ini harus didukung oleh semua warga sekolah. Bukan hanya kepala sekolah saja yang melakukan, namun perlu juga mengajak semua untuk terlibat. Berdasarkan hasil wawancara, diketahui 2 madrasah telah melakukan strategi pemenuhan kelengkapan sarana dan prasarana yaitu MI Ismaria dengan strategi menaikan biaya SPP siswa dan MIN 9 yaitu dengan mengajukan proposal permohonan bantuan kepada PUPR untuk perbaikan bangunan sekolah seperti contoh pembangunan kantin sehat. Sedangkan 3 madrasah lainnya baru sampai pada tahap penyusunan strategi yaitu yang akan dilakukan menjalin kerjasama dengan komite sekolah dan dengan pihak lain seperti perusahaan yang berbadan hukum.

Peneliti menganalisa bahwa hampir seluruh madrasah menaruh harapan adanya bantuan dana dari berbagai pihak, khususnya pemerintah untuk memenuhi kebutuhan sarana dan prasarana sebagai penunjang terciptanya madrasah bersih dan sehat. Upaya madrasah dalam memenuhi kebutuhan sarana dan prasarana selain dari pemerintah juga dari pihak lain seperti perusahaan, perguruan tinggi, atau kelompok-kelompok masyarakat.

Jurnal Dunia Kesmas, Vol. 9 No. 3, Juli 2020, hal. 423-433

ISSN 2301-6604 (Print), ISSN 2549-3485 (Online)

http://ejurnalmalahayati.ac.id/index.php/duniakesmas/index 
Selain pembudayaan perilaku bersih dan sehat, kondisi lingkungan madrasah masih terlihat kotor peneliti berpendapat bahwa warga madrasah belum memiliki kesadaran yang tinggi akan kebersihan lingkungan. Lingkungan kurang sehat dapat menyebabkan berbagai penyakit dan dapat mengganggu kegiatan proses belajar mengajar.

\section{KESIMPULAN}

Berdasarkan uraian di atas dapat disimpulkan bahwa tingkat ketercapaian kelengkapan dan kualitas sarana dan prasarana untuk menunjang terlaksananya perilaku hidup bersih dan sehat masih dalam kategori cukup. Demikian pembudayaan perilaku hidup bersih dan sehat dalam kategori cukup. Secara umum dapat disimpulkan keberhasilan program SDBS baru mencapai predikat cukup. Dalam hal tersebut strategi yang akan dilakukan oleh madrasah ada 2 klasifikasi strategi yang pertama yaitu bersama sama warga sekolah bekerjasama untuk menciptakan sekolah bersih dan sehat di madrasah, dan yang kedua dengan melakukan kerjasama dengan pihak ketiga.

\section{SARAN}

Berdasarkan kesimpulan tersebut disarankan kepala madrasah dan warga madrasah memaksimalkan perannya masing-masing sesuai tupoksinya. Kepala madrasah hendaknya melakukan kerjasama lintas sektoral, puskesmas, perguruan tinggai kesehatan.

\section{DAFTAR PUSTAKA}

Arikunto, S dan Jabar, (2018). Evaluasi Program Pendidikan. 2end edn. Edited by Fatna Yustiani. Jakarta: PT Bumi Aksara.

Devi, R. (2018) Manajemen sarana dan prasarana dalam meningkatkan mutu pembelajaran di smp negeri 23 medan.

Diana, F. et. a. (2014) Pelaksanaan program perilaku hidup versih dan sehat(PHBS) di SD Negeri 001 Tanjung Balai Karimun, 8(1).

Dinas Kesehatan kota Bandar Lampung. 2014. Profil Kesehatan Kota Bandar Lampung 2014. Bandar Lampung.

Kementerian Pendidikan dan kebudayaan. 2013. Panduan Pembinaan Sekolah Dasar Bersih dan Sehat (SD Bersih Sehat). Jakarta.

Kementerian Pendidikan dan Kebudayaan. 2017. Profil Sanitasi Sekolah. Jakarta

Maghfiroh, A. (2016) 'Strategi Kepala Sekolah Meningkatkan Sarana Untuk Menunjang Inovasi Pembelajaran di smk MA'ARIF NU 04 Pakis Kabupaten Malang'.

Notoatmodjo, S. (2010). Promosi Kesehatan Teori dan Aplikasi. Revisi. Jakarta: PT Rineka Cipta.

Presiden RI dan DPR RI. 2009. Undang-Undang Republik Indnesia Nomor 36 Tahun 2009.

Pradita, H. (2017) Implementasi Program Sekolah Sehat Di Sd N Tegalrejo 1, VI(1), pp. 20-28.

Purti D, et.al (2016) 'Pengaruh Sarana dan Prasarana Sekolah dan Motivasi Belajar Siswa Terhadap Prestasi Belajar Siswa Pemasaran di SMK Negeri 1 SUKOHARJO TAHUN AJARAN 2015/2016', (2). 
Sugiyono, (2017). Metode Penelitian Kuantitatif, kualitatif dan R\&D. Bandung: Alfabeta CV.

Sulastri, K. et. al (2014) Hubungan tingkat pengetahuan dengan perilaku anak sekolah tentang hidup bersih dan sehat di sekolah dasar negeri wilayah puskesmas selemadeg timur II, Vol 4.

Zubaidah, S., Ismanto, B. and Sulasmono, B. S. (2017) Evaluasi Program Sekolah Sehat di Sekolah Dasar Negeri, SD Negeri Kutowinangun 04 Salatiga. FKIP Universitas Kristen Satya Wacana. 